Article

\title{
Endlessly Responsible: Ethics as First Philosophy in Stanley Cavell's Invocation of Literature
}

\section{Mette Blok}

Department of Communication and Arts, Roskilde University, 4000 Roskilde, Denmark; mblok@ruc.dk

Received: 31 March 2019; Accepted: 12 June 2019; Published: 17 June 2019

\begin{abstract}
This essay aims to give an overview of the topic ethics and literature in Stanley Cavell's complete oeuvre. It argues that Cavell's preoccupation with literature is, from beginning to end, primarily ethical, even though he takes his point of departure in epistemological skepticism. Recent research on the affinities between Cavell's early writing on Shakespearean tragedy and the ethics of Emmanuel Levinas has helped to establish this but the question of how this part of Cavell's work is related to his later development of Emersonian perfectionism is rarely touched upon. Consequently, this essay further argues that skepticism and perfectionism in Cavell's thinking are two sides of one and the same ethics, which are bound together by the genre of romanticism. While Cavell's work on skepticism is primarily concerned with the other, his work on perfectionism is primarily concerned with the self. Finally, this essay marks the point where Cavell's and Levinas' overall thinking part ways due to the fact that Cavell embraces Emersonian perfectionism.
\end{abstract}

Keywords: Stanley Cavell; ethics; literature; skepticism; tragedy; romanticism; Emersonian perfectionism; Emmanuel Levinas

\section{Introduction}

The death of Stanley Cavell last summer makes it appropriate to say something overall about the relation between ethics and literature in his work and about the surprisingly strong unity of his oeuvre. Viewed chronologically, Cavell's occupation with literature can be divided roughly into three internally related and partly overlapping phases, an early one focusing on skepticism in Shakespeare, a middle one focusing on romanticism primarily in Thoreau, Emerson, Coleridge, and Wordsworth, and a late one focusing on moral perfectionism in a very broad range of works spanning the whole of the Western literary and filmic tradition ${ }^{1}$. Cavell's occupation with traditional philosophical ethics shows a similar but not quite overlapping structure: In The Claim of Reason Part III, he criticizes 20th century analytical moral philosophy from the perspective of ordinary language philosophy; from the 1990s onwards he develops his moral perfectionism, and late in his career he has an essay on his relation to Levinas, What is the Scandal of Skepticism? In this essay, he tries, as if in hindsight, to place his early thinking about acknowledgment and avoidance, developed in two essays of Must We Mean What We Say? and Part IV of The Claim of Reason, as belonging to an ethics of the other, though in a sense different from Levinas' (Newton 1995; Hammer 2002; Rudrum 2013). It is worth noting that this ethics mainly grows out of his readings of Shakespeare, which could be a reason why it is often omitted in philosophical treatments of ethics in Cavell.

The above sketch indicates that the theme 'ethics and literature' in Cavell requires an investigation of the concepts skepticism, romanticism, and moral perfectionism and their internal relations. I am going to argue that they grew out of each other, not only chronologically but also logically, and that

1 This is a rough sketch. Shakespeare, for instance, is a recurring theme in Cavell, also in what I call the middle and late phases. 
romanticism is what binds skepticism and moral perfectionism together: Romanticist texts are both the expression of and the potential recovery from skepticism, thus making possible the achievement of moral perfectionism. (Cavell does not primarily understand romanticism as a literary period but as a genre, which is also to be found in Wittgenstein and Heidegger, for instance.) While Cavell's treatment of skepticism focuses on Shakespearean tragedy, i.e., dramas which are not narrated but performed in the presence of spectators, his engagement with perfectionism tends to prefer film or poetry or narrative fiction-if he includes drama, like Ibsen's A Doll's House, he focuses solely on the content of the play. This essay presents the argument that Cavell's treatment of skepticism and perfectionism are two equally necessary sides of the same ethics: while the concepts of acknowledgment and avoidance stress our relation to the other, perfectionism highlights our relation to ourselves and our endless responsibility for ourselves.

\section{Skepticism}

It seems uncontroversial to say that from his earliest essays in Must We Mean What We Say? (1969) to what would become his last in Philosophy the Day after Tomorrow (2005)—and in a different way in his philosophical autobiography Little Did I Know (2010)—one of Stanley Cavell's main themes, if not the main theme, is the relation between philosophy and literature. It may be somewhat controversial, however, to qualify this by saying that Cavell's work, from beginning to end, is concerned with the relation between ethics and literature. This depends on seeing his early essays on skepticism in Shakespeare as not primarily an exercise in epistemology but rather as a contribution to ethics, and also on accepting his work on romanticism as having to do with ethics in some broad sense (or senses). Furthermore, it seems to involve finding a way to strike the balance, or perhaps even to negotiate, between what could be called Cavell's two main concerns, those of skepticism and moral perfectionism. Notably, Cavell himself hardly ever addresses this issue as a problem, thus indicating that he sees his two concerns as perfectly compatible. Yet this leaves open the question of their internal relation and their respective weight in his overall thinking. If we turn to the growing secondary literature on Cavell or to readings of literature inspired by his readings, we find remarkably little help on this issue; most commentators concentrate either on skepticism or on moral perfectionism, and if they consider both by way of introducing Cavell's complete oeuvre, they tend to treat them separately and have next to nothing to say about their internal relation ${ }^{2}$. Thus, for instance, in recent years Cavell scholarship has offered welcome contributions to the elucidation of the unlikely similarities between Cavellian and Levinasian ethics, prompted by Cavell's own late article from Philosophy the Day after Tomorrow ${ }^{3}$. These comparisons are important, not least because they stress the ethical character of Cavell's early work on Shakespeare, but they sometimes give the impression (Cavell's own article included) that this is all there is to Cavellian ethics whereas, strictly speaking, this is only part of what there is to Cavellian ethics. How do the skepticist part and the perfectionist part of his ethics fit together?

To begin answering this question, I think we should look at the development of Cavell's work chronologically, and I agree that the article What is the Scandal of Skepticism? is a clue to how Cavell himself would have his early work understood. (There are interesting parallels here to Nietzsche's late forewords to his earlier works: he, too, gave them an unequivocally ethical interpretation.) About halfway into his treatment of Levinas, Cavell states: "A measure for me of progress in The Claim of Reason lay in working to do what I called discover the problem of the other, discover it within the means of a tradition of philosophy that has thought to sidestep Fichte and Hegel [ ... ] and, speaking for myself, finds no help in Heidegger's appeal to Mitsein (being with others), which feels to me to

2 As paradigmatic examples of this tendency, I would mention (Mulhall 1994; Hammer 2002; Rudrum 2013; Norris 2017) but there are countless other examples. I do not so much want to criticize this tendency as understand why this is so and what it tells us about Cavell's position.

3 Apart from (Hammer 2002; Rudrum 2013), the relation between Cavell and Levinas is taken up in (Dahl 2014; De Vries 2006; Standish 2007; Stricker 2012). An early contribution from before Cavell's article is (Newton 1995). 
represent something of a philosophical afterthought." (Cavell 2005, pp. 148-49). Clearly, Cavell sees in this early ambition to "discover the problem of the other" the undeniable kinship of his treatment of skepticism regarding others with Levinas' ethics of the other ${ }^{4}$. With this fundamental agreement in place, however, Cavell seems more concerned to probe his differences from Levinas than his similarities with him. These differences all originate in the different role they allow the idea of God and the infinite to play in their respective philosophies. While generally sympathetic towards the use of religious concepts, Cavell stresses that, unlike Levinas, he sees no need for the idea of God in establishing the responsibility for the other; a particular finite other suffices. Thus he asks, almost rhetorically: "But why is the existence of a finite other not sufficient to create the reality of such claims [of gratitude or sympathy or protection or duty or debt or love, M.B.] upon me?" (Cavell 2005, p. 144). Indeed, Cavell draws attention to the fact that in The Claim of Reason his idea or "experiment" was exactly that of "replacing God by a human other" (Cavell 2005, p. 146), be it in acknowledgment of the process of secularization or of his own limitation. That "the other now bears the weight of God", as he expressed it in The Claim of Reason (Cavell 1979, pp. 470, 482), means for Cavell that the self's relation to the other is not primarily characterized by union but by separation. In a pivotal passage at once marking his closeness to and his distance from Levinas, Cavell writes: "Now when I say, in response to Descartes's Third Meditation proof, that in Shakespearean tragedy (immediately in connection with Othello) this traumatic effect of the recognition of the existence of God is replaced by the idea of a finite other, violence and some sense of an infinite nevertheless remain. But in originating now in the face of a finite other, violence and infinitude cannot be thought to arise from a comparison of myself with the other but from a recognition that this particular other, this creature among all the creatures of the earth similar to me, is also, or rather is therefore, absolutely different, separate from me, I would say, wholly other, endlessly other, the one I single out before whom I am I, eternally singled out. It is the unbearable certainty of this separation to which the torture of skepticism over Desdemona's faithfulness is preferable." (Cavell 2005, pp. 145-46). Thus, the other in Cavell is at one and the same time more similar to the self and more different from the self than the other in Levinas ${ }^{5}$. This takes us back to Cavell's early work on skepticism as tragedy and the reason why he turns to Shakespeare and literature.

In The Claim of Reason, Cavell distinguishes between skepticism with respect to external objects and skepticism with respect to others. In the first two parts of the book, he reaches the conclusion that Wittgensteinian criteria are not meant to refute skepticism about the outer world; rather, this kind of epistemological skepticism is always a possibility but the problem does not generalize and-here, Cavell declares his agreement with the philosophical tradition-it cannot be lived. When in the fourth part of the book he turns to skepticism about others, things change dramatically. This kind of skepticism, Cavell contends, can be lived, and it takes the form not primarily of doubt about the other's existence but of denial, avoidance, even annihilation of him or her. What is more, this kind of skepticism also generalizes in the sense that there is no everyday alternative to it; it stems not from doubt in a particular case, but from a general disappointment over the knowledge we (think we) can have about others in their separateness from us. This is what Cavell calls skepticism's interpretation of "a metaphysical finitude as an intellectual lack" (Cavell [1969] 2002, p. 263): we convert the fact of our separateness into a doubt about the other, about his or her faithfulness, for instance. In two essays dating from before The Claim of Reason, Knowing and Acknowledging and The Avoidance of Love, Cavell famously argues that our relation to the world and to others in it is not primarily one of knowing but one of acknowledging, where he wants the concept of acknowledgment to be understood as an existentiale in Heidegger's sense: "The world is to be accepted; as the presentness of other minds

4 Cavell refers primarily to Levinas' essay "God and Philosophy" (Levinas 1998) and also briefly to "Ethics and Spirit" from Difficult Freedom (Levinas 1990).

5 For the loci classici of Levinas' treatment of the other, see Totality and Infinity (Levinas 1969) and Otherwise than Being or Beyond Essence (Levinas 1981). 
is not to be known, but acknowledged." (Cavell [1969] 2002, p. 324). At this level, the concept of acknowledgment is not yet clearly an ethical concept, but it becomes one as soon as the relation to a particular other or particular others comes into play. Cavell shows this in a series of readings of Shakespeare's tragedies, maintaining that "skepticism with respect to the other is not skepticism but is tragedy" (Cavell 2005, p. 150). Here, at the latest, it becomes evident that Cavell's concept of skepticism is not identical with that of the philosophical tradition; his is a much broader concept, encompassing both epistemological and ethical concerns, and indeed, Cavell sometimes says that he regards skepticism with respect to others as more fundamental than skepticism with respect to external objects, thus indicating the primacy of ethics over epistemology in his thinking. This is why it can be confusing that he sometimes speaks of his "epistemological reading of Shakespearean tragedy" (Cavell [1987] 2003, p. 1) or of his "taking tragedy as an epistemological problem" (Cavell [1987] 2003, p. 143). Strictly speaking, it is the other way around: epistemological skepticism is already an interpretation, or intellectualization, of something tragedy is also an interpretation of, namely our human finitude and separateness. Why did Cavell need Shakespeare to show this?

As already mentioned, in The Claim of Reason Cavell took himself to have shown that skepticism cannot be refuted and that there is no alternative to living our skepticism with respect to others. Characterizing the problem of the other in terms of acknowledgment or its failure, avoidance, and further taking the best case of acknowledgment to be the self's exposure to a particular other, Cavell needed descriptions of intersubjectivity or human relationships which were sufficiently detailed or fleshed out to show what acknowledgment or avoidance amounts to in particular cases. He is not claiming that philosophy never provides this or could not in principle provide it, but he found in Shakespearean tragedy a confirmation of his interpretation of skepticism with respect to the other with vast ramifications. First, he could show that Shakespeare's tragic characters are cousins of Descartes in that they take knowledge and doubt to constitute their fundamental relation to the world and others, thus bypassing the acknowledgment we owe each other and shutting themselves out of our common world. In a recapitulation of his work on Shakespeare in Cities of Words, Cavell writes: "My claim for Shakespearean tragedy has been that, in the generation preceding Descartes's beginning of modern philosophy, Shakespeare was already, in the main characters of his tragedies, exploring characters whose destructiveness can be seen to arise out of this epistemological lack of assurance, but in each case directed to a different topic, a different way in which the foundation of a life seems to give way before a moment of doubt, casting the world into a hostile, worthless chaos. In Othello's case it is a doubt, expressed as jealousy, about Desdemona's faithfulness; in the case of King Lear it is about whether he is loved; in Hamlet's case about the worth of human existence, about the curse of being born, of being mortal; in Macbeth's case about the identity or nature of his wife." (Cavell 2004, p. 425). Shakespeare's tragic characters prove for Cavell that skepticism with respect to the other is a cover for a more fundamental failure of acknowledgment and thus ultimately belongs to the order of ethics, not to the order of epistemology. This passage also touches on the question whether skepticism is a historical phenomenon. While it is clear that Cavell sees modern skepticism as arising in the wake of the new science in the sixteenth and seventeenth centuries and culminating in Shakespeare and Descartes, it is also clear that skepticism to him constitutes a possibility inherent in our language and thus our conceptualizing of the world which is not limited to a specific historical period: Skepticism is played out in Wittgenstein's Philosophical Investigations no less than in Shakespeare's tragedies. Second, Cavell's invocation of Shakespeare allowed him to point out a feature of drama in particular and of (some kinds of) literature more generally which was to become increasingly important in his subsequent readings of literature. Not only were these tragedies about the failure of acknowledgment on a thematic level, they were also enacting or performing a best case of acknowledgment for us as spectators, attending the present of the characters in the theatre. Acknowledging a character in a play can teach us something about acknowledgment outside the theatre, and this direct relation to an other, or investment in an other, on the part of both spectator and reader, is something which is rarely found in philosophy. Thus, Shakespeare's dramas allowed Cavell to begin asking what a play or a text does, 
what its work on the spectator or reader is, and why art can have the importance it has for us, why we care about it so much.

\section{Romanticism}

Along with his readings of Shakespearean tragedy, Cavell turned to certain romanticist texts, primarily works by Thoreau, Emerson, Wordsworth, and Coleridge, as further investigations of the skeptical problematic. But while he took skepticism in Shakespeare as having to do with others, the skepticism he found in the romanticists was rather concerned with the self and its relation to (or with) the world. And while there was no sign of an overcoming of skepticism in Shakespeare's tragedies, the romanticist texts pointed to what Cavell would come to call a recovery from skepticism. In itself, Cavell's turn to romanticism was natural and unsurprising. After all, romanticism can be seen as the bonding of philosophy and literature (or poetry), and Cavell's claim for Emerson's writing in particular is exactly that it constitutes "a fair realization" of this bonding (Cavell 1988, p. xii). Furthermore, Cavell uncontroversially took romanticism to be an answer to what he calls Kant's settlement of the skeptical problematic, where knowledge of the thing in itself is given up for knowledge of appearances (Cavell 1988, pp. 29-31). Thus, he describes his understanding of romanticism's struggle with skepticism and with philosophy's responses to skepticism as "the thought of romanticism as working out a crisis of knowledge, a crisis I have taken to be (interpretable as) a response at once to the threat of skepticism and to a disappointment with philosophy's answer to this threat, particularly as embodied in the achievement of Kant's philosophy [ ... ]. Romanticism's work here interprets itself [ ... ] as the task of bringing the world back, as to life. This may, in turn, present itself as the quest for a return to the ordinary, or of it, a new creation of our habitat; or as the quest, away from that, for the creation of a new inhabitation" (Cavell 1988, pp. 52-53).

If Cavell's turn to romanticist texts is thus quite logical, his claim as to what constitutes skepticism and the alleged recovery from skepticism in these texts is innovative and surprising. Again, it helps to think of Cavell's understanding of skepticism as moving from an epistemological to a more fundamental ethical or existentialist register. While in The Claim of Reason he took Shakespearean tragedy to be the working out of skepticism with respect to the other, now, in the romanticist texts, he takes skepticism with respect to the self, its language, and its world to be "the playing out of a tragedy" in such a way that "our ordinary lives partake of tragedy in partaking of skepticism" (Cavell 1988, p. 9). This skepticism takes on different forms in the different writers but common to them is a certain distance from the world, a lost intimacy with the world, causing despair both linguistically and existentially. Thus, Cavell describes this skepticism of our ordinary lives as follows: "Thoreau calls this everyday condition quiet desperation; Emerson says silent melancholy; Coleridge and Wordsworth are apt to say despondency or dejection; Heidegger speaks of it as our bedimmed averageness; Wittgenstein as our bewitchment; Austin both as a drunken profundity [ ... ] and as a lack of seriousness." (Cavell 1988). This quotation also testifies to the fact that Cavell counts Heidegger, Wittgenstein, and Austin as romanticist writers in his sense, and in particular, he claims that Emerson and Thoreau "underwrite" the concept of the ordinary in the ordinary language philosophy of Wittgenstein and Austin in their attention to the concepts of "the common, the familiar, the near, the low" (Cavell 1988, p. 4). This is a bold claim because like the concept of skepticism, the concept of the ordinary now takes on a meaning which is much closer to ethical and existentialist concerns than what we were used to from standard readings of ordinary language philosophy. This concept of the ordinary is central to Cavell's description of the potential recovery from skepticism in romanticist texts.

In his book Hearing Things, Timothy Gould briefly states that what binds skepticism and perfectionism together in Cavell is the concept of the voice: while skepticism suppresses the individual voice, perfectionism exalts in it (Gould 1998, p. 210). Even though I do not disagree with this, I think that the concept of the ordinary is a better candidate for this role because of its centrality to Cavell's readings of his romanticist texts (an implication of the interpretation in this essay is that these texts 
are both skepticist and perfectionist) ${ }^{6}$. So what does recovery from skepticism look like in Cavell's readings? Again, it takes on different forms in the different writers but common themes are, as we saw above, the restoration of the lost intimacy with the world and the return to the ordinary or everyday which is connected to ideas of domestication and inhabitation. More concretely, it can consist in taking a (new) interest in our ordinary lives or in presenting marriage as intimacy on a small scale, in its turn interpreting the concepts of domestication and the everyday. The relation to the world, which is won in this recovery from skepticism, is still one of acknowledgment, or of reception, and the promise for the self is the promise of nothing short of redemption. To Cavell, this relation of the self to the world is epitomized in the following quotation from Thoreau's Walden, which he keeps coming back to throughout his writings: "You only need sit still long enough in some attractive spot in the woods that all its inhabitants may exhibit themselves to you by turns." (Cited after Cavell 1988, p. 21).

As in his readings of Shakespeare's tragedies, Cavell's claim for his romanticist texts is that they are not only about skepticism on a thematic level but that they enact or perform skepticism and the recovery from it in a way that directly implicates the reader. Thus, for instance, he says of his reading of Coleridge's The Rime of the Ancient Mariner that it "takes the poem as an enactment [... ] of skepticism's casual step to the path of intellectual numbness, and then of the voyage back to (or toward) life, pictured as the domestic." (Cavell 1989, p. 57). In this case, the idea is that the mariner is an example, or representative, to the reader of a working through and recovery from skepticism. A prominent Cavellian inversion here is that of the reader being read by the text, so that the text works as an other to the reader and makes possible a transformation of the self, in some cases even promises redemption. Thus, Cavell develops an idea of what he calls redemptive reading, again immediately in connection with Thoreau's Walden, where reading is understood as a therapeutic endeavor on the model of psychoanalysis. Again, this is not a defense of psychoanalytic readings of texts, but a question of the reader being subjected to analysis through the work of the text (cf. Cavell [1984] 1988, p. 52). So while there is still an other in play here, the focus of interest seems to have shifted with Cavell's turn to romanticist texts: where in the case of Shakespeare's tragedies the main focus was on the self's acknowledgment of the other, in the case of romanticism the main focus is on, we could say, the self's acknowledgment of itself, or on self-recovery. But the claim is that this is impossible without some intervention of an other.

\section{Perfectionism}

Cavell's development in Conditions Handsome and Unhandsome (1990) of what he calls "Emersonian Perfectionism" is the most straightforwardly ethical of his invocations of literature. As the name indicates, it takes its point of departure in Emerson and thus constitutes a natural extension of Cavell's writing on romanticism. (Tellingly, very many romanticist works find their way to Cavell's open list of perfectionist works in Conditions Handsome and Unhandsome, p. 5.) Emersonian perfectionism is meant to be in dialogue with prominent ethical theories, especially Kantianism and utilitarianism, but Cavell always stresses that it is not itself an ethical theory but rather a dimension of moral thinking to be found from Plato (another founding father of Cavell's version of perfectionism) to our day, and not only in philosophy but also in literature and film. The central idea of Emersonian perfectionism is that of being true to oneself, and the main focus is not on good or right action in particular situations but on the whole of one's life and the state of one's soul, i.e., on the questions of how one should live and what kind of person one aspires to be (cf. Cavell 2004, p. 11). Summing up his work on perfectionism in Cities of Words, Cavell says that there are two dominating themes of perfectionism, the first being that the self is always becoming, so that it is best thought of as on a journey of education or cultivation or

6 By saying that what binds skepticism and perfectionism together in Cavell is the concept of the ordinary found in romanticist texts, I do not mean to imply that these are similar concepts but rather that the ordinary is the cure for skepticism, thus paving the way for perfectionism. 
transformation, and the second being that the other, who inspires or accompanies this process, is best thought of as "the Friend" (Cavell 2004, pp. 26-27). Perfectionism thus places tremendous value on friendship which explains why marriage becomes so important in Cavell's thinking. This bears on a worry one could have regarding perfectionism's inherent individualism and the impression it can give of not having to do with ethics after all, since it is focused primarily on the self and not on the other. Cavell is acutely aware of this worry and addresses it as follows: "From the perspective of these theories [Kantianism and utilitarianism, M.B.], Moral Perfectionism, seeming to found itself, let us say, on a concept of truth to oneself, may appear not to have arrived at the idea, or to disdain it, of other persons as counting in moral judgment with the same weight as oneself, hence to lack the concept of morality altogether." (Cavell 1990, p. 2). Cavell's answer to this worry would be that Emersonian perfectionism is concerned with the other in a positive way and that in a certain sense the other even carries more weight than the self but this other is thought of as an exemplary friend, who attracts the self to his or her higher standard, not as an object of duty or obligation. Central to Emersonian perfectionism is the idea of becoming morally intelligible to oneself and to others, and here again the friend is indispensable as "the figure [ ... ] whose conviction in one's moral intelligibility draws one to discover it, to find words and deeds in which to express it, in which to enter the conversation of justice." (Cavell 1990, p. xxxii). Indeed, if there is an imperative in Emersonian perfectionism it is an "imperative to conversation" (Cavell 2004, p. 174), where conversation is understood not only as talking but as a way of living together (with one other or in society at large)—a way of living which mostly favors the virtues of "listening, the responsiveness to difference, the willingness for change" (Cavell 2004). Thus, when Cavell says that the self has "absolute responsibility to itself" (Cavell 1990, p. xxvii), this is not meant as if in competition with the responsibility for others but as a statement of the fact that only the self can be responsible for expressing itself, for making itself morally intelligible to itself and others. The work on the self undertaken in Emersonian perfectionism is related to Aristotle's concept of philautia and Foucault's care of the self where being on friendly terms with oneself is seen as a precondition for being on friendly terms with others, so that the self is also an other to itself and the other is another self.

What characterizes the works of literature for which Cavell claims perfectionism or perfectionist features? In one word, we could say that they are all in one way or another edifying; there is some story of education, cultivation or transformation of the protagonist or of his or her society for the better. The prototype of a perfectionist work is the "Bildungsroman"; indeed, some of the plays Cavell draws on, like Ibsen's A Doll's House or Shaw's Pygmalion, evidently participate in this genre even though they are not novels. (Of course, this also holds for the genre of films Cavell investigates in Pursuits of Happiness, the so-called "remarriage comedies".) Likewise, even if the literary works Cavell points to are very often realist and early modernist novels by for instance Dickens, Eliot, Melville, Twain, Dostoevsky, or James, he also includes poetry, like Whitman, Dickinson, or Stevens, and even Beckett's Endgame. What these works have in common is a call for change, a call for transformation of the self and of society, which Cavell describes as follows: "The vision of the demand for a transfigured future, expressed as a sense of the exhaustion of present culture, perhaps accompanied by a demand for the renewal of culture, call it a vision of modernity, seems shared by many of the major writers [ ... ] of the nineteenth and twentieth centuries." (Cavell 2004, p. 218). The critique of society inherent in these works is often a critique of society's values, specifically of its morality, and thus "a major theme of modern literature" emerges: "the salvation of the self through the repudiation of morality" (Cavell 1979, p. 269). For instance, this is how Cavell reads Kleist's The Marquise of O and Ibsen's A Doll's House: The marquise and Nora both repudiate the morality of their societies, and they repudiate some of our most prominent ethical theories as well, since we cannot make sense of their actions on deontological or utilitarian grounds. Yet we feel that the marquise is right when she forgives the count and that Nora is justified when she leaves Torvald. To Cavell, this is literature at its best: teaching philosophy an ethical lesson. 
When it comes to perfectionist literature's work on the reader, there is a clear difference from the situation of a spectator at a Shakespearean tragedy: whereas the tragedy, in Cavell's words, could not happen without us, because it takes place in the present and the spectator's acknowledgment of the characters' separateness is needed for the tragedy to do its work, narrative fiction typically takes place in the past and is not in the same way dependent on the reader's acknowledgment of its characters: it happened without us. What we can do as readers and what we are invited to do by perfectionist works, is to see the work (or its protagonist) as an exemplary other and let it transform us. But what about Ibsen's and Shaw's plays, one could ask? Are not Nora and Eliza dependent on the spectator's acknowledgment for the plays to do their work? I think we would have to say that in a straightforward sense they are, but that since A Doll's House and Pygmalion are not tragedies but something like the opposite of tragedies (by which I do not mean comedies), there is no specific problem with acknowledgment here, we grant it gladly and, as it were, unawares. Perhaps this even goes some way to explain the relation between skepticism and perfectionism in Cavell: They are two different modi of acknowledgment where skepticism is the deficient modus (this is not to say that it is less common, of course). This would also seem to be confirmed by the fact that Emersonian perfectionism conceives of the other as the Friend, since a friend is per definition someone we acknowledge (though of course we can fail to acknowledge a friend in a particular case).

\section{Levinas or Emerson?}

It is time to try to reach a conclusion about skepticism's place in Cavell's overall thinking and thereby about his general similarities and dissimilarities with Levinas. I hope to have shown that Cavell's invocation of literature is, from beginning to end, primarily ethical and that ethics is in this straightforward sense first philosophy to him. It is also first philosophy in the sense that ethics has primacy over epistemology in Cavell: acknowledgment is more fundamental than knowledge. But this is in itself, unproblematically, an ontological assertion because, unlike Levinas, Cavell does not understand ethics metaphysically or religiously as opposed to something called ontology. (Neither does he understand ontology metaphysically.) ${ }^{7}$ To return to Cavell's invocation of Heidegger, acknowledgment is an existentiale; it is our way of being in this world, not something which is put into us from outside this world.

It is telling that Cavell (and his interpreters) always invoke Levinas in connection with skepticism, never in connection with perfectionism. What Cavell recognizes of his own thinking in Levinas, apart from "phenomenological coincidences" (Cavell 2005, p. 152), is the description of the failure of acknowledgment and the idea that in our encounter with the other a certain passiveness is called for. This is what he says about it in Cities of Words: "What I have said about skepticism with respect to the other can be related to Levinas's claims for the other. Levinas requires our recognition of the other to be taken in passiveness, a way of saying that we are subject to the other and, contrariwise, that the other is presented to us in an accusatory mode, as if reflecting our inability to recognize him or her. As if the alternative to passiveness-receptiveness-is rejection, which I take as a certain kind of confirmation of the intuition I have expressed in saying that skepticism with respect to the other, the failure of a proof of the existence of the other, is not a discovery but an annihilation." (Cavell 2004, p. 117). In this passage, Cavell avoids commenting on the generality of Levinas' idea that the other is presented to me as accusatory or persecutory and also on the fact that there is a fundamental asymmetry in our relation according to Levinas ${ }^{8}$. In What is the Scandal of Skepticism? he addresses these issues a little more directly but still primarily in an effort to understand Levinas, not to distance himself from him. I think, however, that Cavell and Levinas part ways on exactly these points. From What is the Scandal of Skepticism?: "Take the repeated idea of the other as accusatory or persecutory, as naming me—so

7 For Levinas' mature understanding of ontology or "Being", see Otherwise than Being or Beyond Essence (Levinas 1981).

8 For these ideas in Levinas, see the classical formulations in Totality and Infinity and Otherwise than Being or Beyond Essence. 
Levinas likes to put the matter-in the accusative case. Do I understand this as directed to, perhaps as a projection of, my murderousness? Or is my original narcissism (that is, my state before God's infusion of infinity has shattered it) in itself a sufficient cause of moral guilt, or debt? Either way, beginning with murderousness or with narcissism, I might imagine a basis for recognizing responsibility toward the other, as a kind of reparation for my having failed to acknowledge the other." (Cavell 2005, pp. 147-48). Again, this is a perfect description of Cavell's description of skepticism. But the trouble is that Cavell's ethics does not generally begin with murderousness or narcissism, and his primary figuration of the other is not as in Levinas "the widow, the orphan, and the stranger" (Cavell 2005, p. 147) but, as shown, the Friend. Furthermore, the self's relation to this friend is not asymmetrical but has a reciprocity, which is underscored by the weight Cavell assigns to the concept of conversation. (One may ask if the relation to the unacknowledged other is asymmetrical in Cavell. I would say that it is not, at least not in any fundamental or ontological sense, only in the sense that I am the one who has failed if I do not acknowledge the other.) Indeed, if there is an ethical asymmetry between the self and the other according to Cavell, it consists in the fact that I have infinite responsibility for myself and only finite responsibility for others (cf. Cavell 2005, p. 144). Again, this does not mean that I come before others or count more than them but that I must take responsibility for all of my life, all my interactions with others included. As Cavell says: "It is the idea of the finite human being as possessed of infinite responsibility — or say of the unending demand for responsiveness, to itself and others (a function of its perpetual expressiveness)" (Cavell 2005, p. 143). The responsibility is infinite, the demand for responsiveness unending, because skepticism does threaten our everyday lives with each other in the form, as Cavell sometimes says, of the little deaths we afford each other, often without even noticing. But skepticism or tragedy is only half of our lives, and not the most important one, according to Cavell. The other half is romance.

Funding: This research received no external funding.

Acknowledgments: I am very grateful to Adam Zachary Newton for inviting me to contribute to this special issue on a topic so central to me.

Conflicts of Interest: The author declares no conflict of interest.

\section{References}

Cavell, Stanley. 2002. Must We Mean What We Say? A Book of Essays. Updated Edition. Cambridge: Cambridge University Press. First published 1969.

Cavell, Stanley. 1988. Themes Out of School. Effects and Causes. Chicago: The University of Chicago Press. First published 1984.

Cavell, Stanley. 2003. Disowning Knowledge. In Seven Plays of Shakespeare. Updated Edition. Cambridge: Cambridge University Press. First published 1987.

Cavell, Stanley. 1979. The Claim of Reason. Wittgenstein, Skepticism, Morality, Tragedy. Oxford: Oxford University Press.

Cavell, Stanley. 1988. In Quest of the Ordinary. Lines of Skepticism and Romanticism. Chicago: The University of Chicago Press.

Cavell, Stanley. 1989. This New Yet Unapproachable America. Lectures after Emerson after Wittgenstein. Albuquerque: Living Batch Press.

Cavell, Stanley. 1990. Conditions Handsome and Unhandsome. The Constitution of Emersonian Perfectionism. Chicago: The University of Chicago Press.

Cavell, Stanley. 2004. Cities of Words. Pedagogical Letters on a Register of the Moral Life. Cambridge: The Belknap Press of Harvard University Press.

Cavell, Stanley. 2005. Philosophy the Day after Tomorrow. Cambridge: The Belknap Press of Harvard University Press.

Dahl, Espen. 2014. Stanley Cavell, Religion, and Continental Philosophy. Bloomington: Indiana University Press.

De Vries, Hent. 2006. From "ghost in the machine" to "spiritual automaton": Philosophical meditation in Wittgenstein, Cavell, and Levinas. International Journal of Philosophy of Religion 60: 77-97. [CrossRef] 
Gould, Timothy. 1998. Hearing Things. Voice and Method in the Writing of Stanley Cavell. Chicago: The University of Chicago Press.

Hammer, Espen. 2002. Stanley Cavell. Skepticism, Subjectivity, and the Ordinary. Cambridge: Polity Press.

Levinas, Emmanuel. 1969. Totality and Infinity: An Essay on Exteriority. Translated by Alphonso Lingis. Pittsburgh: Duquesne University Press.

Levinas, Emmanuel. 1981. Otherwise Than Being or Beyond Essence. Translated by Alphonso Lingis. The Hague: Martinus Nijhoff.

Levinas, Emmanuel. 1990. Ethics and Spirit. In Difficult Freedom: Essays on Judaism. Translated by Sean Hand. Baltimore: Johns Hopkins University Press.

Levinas, Emmanuel. 1998. God and Philosophy. In Of God Who Comes to Mind. Translated by Bettina Bergo. Stanford: Stanford University Press.

Mulhall, Stephen. 1994. Stanley Cavell: Philosophy's Recounting of the Ordinary. Oxford: Oxford University Press. Newton, Adam Zachary. 1995. Narrative Ethics. Cambridge: Harvard University Press.

Norris, Andrew. 2017. Becoming Who We Are: Politics and Practical Philosophy in the Work of Stanley Cavell. Oxford: Oxford University Press.

Rudrum, David. 2013. Stanley Cavell and the Claim of Literature. Baltimore: The Johns Hopkins University Press.

Standish, Paul. 2007. Education for Grown-ups, a Religion for Adults: Skepticism and Alterity in Cavell and Levinas. Ethics and Education 2: 73-91. [CrossRef]

Stricker, Bernhard. 2012. Die ethische Bedeutung des Skeptizismus: Stanley Cavell und Emmanuel Lévinas. Phänomenologische Forschungen 127-61.

(C) 2019 by the author. Licensee MDPI, Basel, Switzerland. This article is an open access article distributed under the terms and conditions of the Creative Commons Attribution (CC BY) license (http://creativecommons.org/licenses/by/4.0/). 